\title{
Plasma urea nitrogen and progesterone concentrations and follicular dynamics in ewes fed proteins of different degradability ${ }^{1}$
}

\section{Gustavo Bianchi Lazarin², Nadja Gomes Alves², Juan Ramon Olalquiaga Perez ${ }^{2}$, Renato Ribeiro de Lima ${ }^{3}$, Iraides Ferreira Furusho Garcia ${ }^{2}$, Antônio José Neto ${ }^{2}$, Daniel Navarro Cardoso do Vale $^{2}$, Gabriela de Abreu Saunders ${ }^{2}$}

\author{
${ }^{1}$ Apoio financeiro: Fundação de Amparo à Pesquisa do Estado de Minas Gerais - FAPEMIG e Conselho Nacional de Desenvolvimento \\ Científico e Tecnológico - CNPq. \\ ${ }^{2}$ Departamento de Zootecnia, Universidade Federal de Lavras. \\ ${ }^{3}$ Departamento de Ciências Exatas, Universidade Federal de Lavras.
}

\begin{abstract}
The effects of overfeeding with protein of different degradability on body condition, plasma urea nitrogen and progesterone concentrations, ovulation number and follicular dynamics were assessed in Santa Ines ewes. Twelve ewes were assigned to a randomized block design according to body weight and received overfeeding with soybean meal or with corn gluten meal or maintenance diet for 28 days before ovulation and during the next estrous cycle. Blood samples were taken on days $7,14,21$, and 28 after the beginning of treatments for analysis of plasma urea nitrogen and on days $3,6,9,12$, and 15 into the estrous cycle for analysis of plasma urea nitrogen and progesterone. Follicular dynamics was monitored daily by ultrasound during one estrous cycle. Dry matter and crude protein intake, weight gain, plasma urea nitrogen concentration before ovulation, number of ovulations, diameter of the largest follicle of the 1 st and of the $2 \mathrm{nd}$ waves and the growth rate of the largest follicle of the 1 st wave were higher in the ewes that received overfeeding. The growth rate of the largest follicle of the 3rd wave was higher in the ewes fed maintenance diet. The back fat thickness, plasma urea nitrogen before ovulation and progesterone concentrations, diameter of the largest follicle of the 2 nd wave and growth rate of the largest follicle of the 3rd wave were higher in ewes that received overfeeding with soybean meal. The growth rate of the largest follicle of the 1st wave was higher in ewes that received overfeeding with corn gluten meal. Overfeeding with protein-rich feeds may increase the ovulation number and with soybean meal, it may be effective in increasing plasma progesterone concentration in ewes.
\end{abstract}

Key Words: corn gluten meal, flushing, ovarian follicles, ovulation number, soybean meal

\section{Introduction}

Nutrition plays an important role as it affects directly and indirectly both physiology and reproductive performance. A nutritional strategy that may be used to enhance ovulation rate and, consequently, prolificacy, is overfeeding or flushing, which consists in increasing nutrition levels in ewes before mating. The effects of overfeeding with high-energy diets are well known (Rhind et al., 1989; Viñoles et al., 2008); however, few studies have verified this with protein-rich feeds. Some authors have demonstrated that overfeeding with protein feeds increased ovulation rate (Molle et al., 1995, 1997), while the same variable was unaltered by overfeeding with proteins of different degradability (Branca et al., 2000; Saunders et al., 2010). Nevertheless, in none of these studies were ovarian follicular dynamics and plasma progesterone concentration assessed.
High-energy diets stimulate follicular development (Armstrong et al., 2001; Webb et al., 2004). However, there is still controversy on the effects of diets rich in crude protein (CP), rumen-degradable protein (RDP) and non-protein nitrogen (NNP) on ovarian follicular dynamics (GarciaBojalil et al., 1998; Laven et al., 2004; Alves et al., 2011).

Blood progesterone concentration can be influenced by feed intake and, possibly, by excess protein in the diet. In ewes, an inverse relation between the dry matter intake and plasma progesterone concentration has been observed (Parr et al., 1993; McEvoy et al., 1995; O’Callaghan et al., 2000). The excess of CP in the diet was related to lower (Jordan et al., 1983; Sonderman \& Larson, 1989) or higher (Berardinelli et al., 2001) plasma progesterone concentration.

The objectives of this study were to assess the effects of overfeeding with proteins of different degradability for 28 days before ovulation and during the following estrous 
cycle on body condition, plasma urea nitrogen (PUN) and progesterone concentrations, number of ovulations and ovarian follicular dynamics in Santa Ines ewes.

\section{Material and Methods}

The experiment was conducted at the Sheep Sector of the Animal Science Department of Universidade Federal de Lavras (UFLA), between September and December 2008. Twelve Santa Ines ewes with body condition score (BCS) between 2.5 and 3.0 (on a scale of 0 to 5 , in which $0=$ emaciated and $5=$ overfat, according to Gordon, 1997) and body weight of $44 \pm 10 \mathrm{~kg}$ were assigned in blocks according to their body weight ( 54 to $46.5 ; 46$ to $44.5 ; 44$ to 39.5 ; and 39 to $36 \mathrm{~kg}$ ). The ewes were kept in individual pens.

Based on the recommendations of the AFRC (1993), two diets with the same amount of energy and nitrogen and different protein sources and RDP in DM were formulated to promote daily weight gain of $100 \mathrm{~g}$, as well as a maintenance diet (Table 1), resulting in three treatments: overfeeding with soybean meal $(n=4)$, overfeeding with corn gluten meal $(n=4)$ and maintenance $\operatorname{diet}(n=4)$. Diets were supplied as a whole mix at 7:00 and 16:00h for 28 days before the date expected for hormone-induced ovulation and during the following estrous cycle, totaling, on average, 45 days.

The diet supplied to meet the maintenance requirements provided no orts. The orts of ewes that received overfeeding were collected and weighed before the morning feed to determine dry matter and nutrient intake. Samples of orts from each ewe and of corn silage were taken daily and stored at $-20{ }^{\circ} \mathrm{C}$. Composite samples of every week for orts from each ewe and for corn silage, and a sample of soybean meal, corn gluten meal and citrus pulp were assessed for dry matter (DM), CP, ether extract (EE) and ash levels (AOAC, 1990). The neutral detergent fiber (NDF) was determined by an ANKON $^{\circledR}$ Fiber Analyzer. Non-fiber carbohydrates (NFC) were calculated by difference $100-(\% \mathrm{CP}+\% \mathrm{EE}+$ $\% \mathrm{NDF}+\% \mathrm{Ash}$ ).

Ewes were weighed and the BCS was assessed on the first day the diets were supplied and then every seven days until the end of the experiment. The BCS was assessed by handling over and around the backbone, in a scale of 0 to $5(0=$ emaciated and $5=$ overfat, according to Gordon, 1997) . On the last day of supplying diets, the rib-eye area (REA) and the back-fat thickness (BFT) were measured after trichotomy in the backbone, between the 12th and 13th right ribs, transversally to the longissimus dorsi muscle, through an ultrasound scanner (ALOKA SSD-500, Aloka Co., Ltd., Tokyo, Japan) equipped with a $3.5 \mathrm{MHz}$ linear array transducer.

The estrous synchronization began on the 17 th day after the diets were first supplied. An intravaginal sponge containing $60 \mathrm{mg}$ of medroxyprogesterone acetate (MAP$60^{\circledR}$, Tecnopec, São Paulo, Brazil) was inserted for 11 days. Nine days after the sponge insertion, $240 \mathrm{IU}$ of eCG (Novormon ${ }^{\circledR}$, Syntex S.A., Buenos Aires, Argentina) and

Table 1 - Ingredient and chemical composition of the overfeeding diets formulated with soybean meal or corn gluten meal and of the maintenance diet

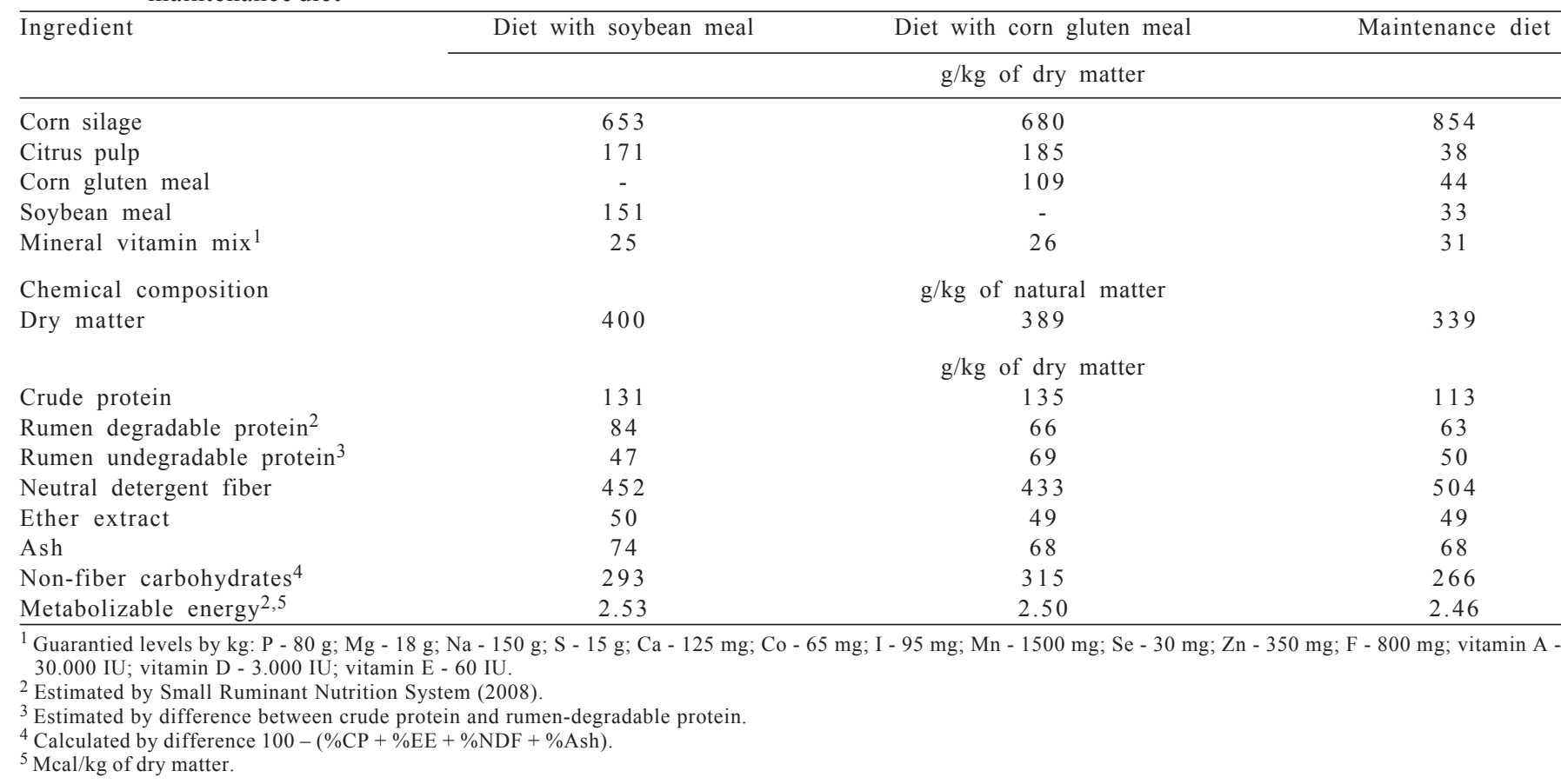


$50 \mu \mathrm{g}$ of cloprostenol (Prolise ${ }^{\circledR}$,ARSA S.R.L., Buenos Aires, Argentina) were administered (i.m.). To avoid vaginitis $0.25 \mathrm{~mL}$ of oxytetracycline were applied in each sponge. From twelve hours after the sponge was removed, the estrous manifestations were monitored at 8:00 and at 17:00 with teaser rams.

Blood samples from all ewes were collected via jugular vein puncture in EDTA vacuntainer tubes on days 7, 14, 21 and 28 after the beginning of the supply of diets to determine PUN concentration, and on days 3, 6, 9, 12 and 15 of the estrous cycle to determine PUN and progesterone concentrations. The samples were taken four hours after the feeding and were centrifuged at $1.582 \mathrm{xg}$ for 10 minutes to obtain plasma. Plasma urea concentration was determined by enzymatic-colorimetric method using a commercial kit (Urea 500, DOLES Reagents and Equipment for Laboratories LTD, GO, Brazil). The urea values were converted into $\mathrm{N}$-urea, multiplying by 0.4666 , equivalent to the percentage of nitrogen in the urea molecule. The progesterone analyses were done at the Scanlab Diagnostics Laboratory Ltd., Belo Horizonte, Minas Gerais, by Enzyme Linked Immune Sorbent Assay (ELISA) using a commercial kit (Direct Progesterone ELISA Kit, Diagnostics Biochem Canada Inc., London, Ontario, Canada). The assay sensitivity was $0.1 \mathrm{ng} / \mathrm{mL}$.

Transrectal ultrasonography of the ovaries was performed daily from the day of estrus, using an ultrasound scanner (ALOKA SSD-500, Aloka Co., Ltd., Tokyo, Japan) equipped with a $5 \mathrm{MHz}$ linear array transducer. The ovulations were determined by the disappearance of dominant follicles and the subsequent formation of corpus luteum (CL). The ovulatory follicle diameter was determined by the average diameter of all the follicles ovulated after estrous synchronization. The interval of ovulations was defined as the number of days between ovulation after estrous synchronization and the following ovulation and was used to define the estrous cycle length.

All follicles $\geq 3 \mathrm{~mm}$ in diameter in each ovary and the CL area were measured. Each follicle $\geq 3 \mathrm{~mm}$ in diameter was identified by a letter and its location was mapped in relation to the other follicles and CL (Ginther et al., 1995). The diameters of the follicles in both ovaries and the CL areas were put on a table and plotted into graphs for evaluation of the growth and regression profiles.

The follicular wave was identified by the growth of a follicle that reached a diameter $\geq 4 \mathrm{~mm}$, individually or as part of a cohort. Day of emergence of wave was the day of emergence of the largest follicle of that wave. The end of a non-ovulatory wave was defined as the day on which the last follicle in regression of that wave reached $3 \mathrm{~mm}$. The wave length was defined as the number of days between the wave emergence and its end. The interval of waves was the number of days between the emergence of two consecutive waves. The number of follicles in each wave was determined by the number of follicles identified. An identified follicle was a $3 \mathrm{~mm}$ follicle observed for at least 3 consecutive days or a follicle that increased from $3 \mathrm{~mm}$ to $4 \mathrm{~mm}$ in one day for the following (Evans et al., 2000). Day of emergence of a follicle was the day that the follicle was $3 \mathrm{~mm}$ in diameter, with an increase to $\geq 4 \mathrm{~mm}$ in the following day (Ginther et al., 1995). When a follicle was first detected at $\geq 4 \mathrm{~mm}$ in diameter, the day of emergence was retrospectively determined, considering a growth rate of $1 \mathrm{~mm} /$ day. The growth phase of the largest follicle per wave was the number of days necessary for the follicle to grow from $3 \mathrm{~mm}$ (emergence) to its largest diameter (Evans et al., 2000). The growth rate of the largest follicle per wave ( $\mathrm{mm} /$ day) was the difference between its maximum and minimum diameter $(3 \mathrm{~mm})$ divided by the growth phase. The maximum diameter of the largest follicle per wave was calculated by the average of its two largest diameters.

The characteristics of waves and follicles were statistically analyzed only for animals which presented three follicular waves. Of the ewes that received the maintenance diet, only one presented three follicular waves, so only the data from this ewe were included in these analyses, thus the standard error of the mean was not generated.

The effects of diets on DM and nutrient intake, weight gain, average daily weight gain, BCS, REA, BFT, interval of ovulations, number of ovulations and average ovulatory follicle diameter were analyzed by variance analyses, using the GLM procedure of SAS (Statistical Analysis System, version 6.11), according to the model: $\mathrm{y}_{\mathrm{ij}}=\mu+\mathrm{b}_{\mathrm{j}}+\mathrm{t}_{\mathrm{i}}+\mathrm{e}_{\mathrm{ij}}$ (1), in which: $y_{i j}=$ observed value of diet $\mathrm{i}$ on block $\mathrm{j} ; \mu=$ constant inherent to every observation; $b_{j}=$ effect of block $j$, with $j=$ $1,2,3,4 ; \mathrm{t}_{\mathrm{i}}=$ effect of diet $\mathrm{i}$, with $\mathrm{i}=1,2,3 ; \mathrm{e}_{\mathrm{ij}}=$ random error associated to each $\mathrm{y}_{\mathrm{ij}}$ observation, independent and identically distributed following a normal distribution.

The PUN and progesterone concentrations were analyzed in a subdivided plots arrangement, with the factor time in the subplots. The statistical model utilized was $\mathrm{y}_{\mathrm{ijk}}=\mu+\mathrm{b}_{\mathrm{j}}+\mathrm{t}_{\mathrm{i}}+\mathrm{e}_{\mathrm{ij}}+\mathrm{d}_{\mathrm{k}}+\mathrm{td}_{\mathrm{ik}}+\mathrm{E}_{\mathrm{ijk}}$ (2), in which: $\mathrm{y}_{\mathrm{ijk}}=$ observed value of diet $\mathrm{i}$ on block $\mathrm{j}$ and on time $\mathrm{k} ; \mu=$ constant inherent to every observation; $b_{j}=$ effect of block $j$, with $\mathrm{j}=1,2,3$ and $4 ; \mathrm{t}_{\mathrm{i}}=$ effect of diet $\mathrm{i}$, with $\mathrm{i}=1,2,3 ; \mathrm{e}_{\mathrm{ij}}=$ experimental error associated to the plot, considered independent and identically distributed following a normal of zero mean and variance $\varphi^{2} ; \mathrm{d}_{\mathrm{k}}=$ effect of time $\mathrm{k}$; with $\mathrm{k}=1,2,3,4$ or $1,2,3,4,5 ; \mathrm{td}_{\mathrm{ik}}=$ interaction between diet and time; $\mathrm{E}_{\mathrm{ijk}}=$ experimental error associated to the subplot, 
considered independent and identically distributed following a normal of zero mean and variance $\sigma^{2}$.

The analyses of follicular dynamics were conducted utilizing the methodology of generalized linear models (Mc Cullagh \& Nelder, 1989). For variables follicular growth rate and maximum diameter of the largest follicle, the normal distribution with identity link function was considered. Poisson distribution and logarithmic link function and independence of observations were considered for variables day of emergence of wave, wave end, wave length, interval of waves, number of follicles in the wave, day of the maximum diameter of the largest follicle and growth phase of the largest follicle. For all the variables, the model of randomized blocks design, given as (1) was considered as linear predictor.

Means were compared by orthogonal contrasts, when the $\mathrm{F}$ test for the effect of diet was significant at $\mathrm{P}<0.05$ and tended to be significant at $\mathrm{P}<0.10$ : contrast $1=$ (soybean meal and corn gluten meal) versus maintenance: $\mathrm{Y}_{1}=\mathrm{m}_{1}+$ $\mathrm{m}_{2}-2 \mathrm{~m}_{3}$ and contrast $2=$ soybean meal versus corn gluten meal: $\mathrm{Y}_{2}=\mathrm{m}_{1}-\mathrm{m}_{2}$.

\section{Results and Discussion}

The DM and nutrient intake was higher $(\mathrm{P}<0.01)$ by overfed ewes, in comparison with those which received the maintenance diet. However, it was not different $(\mathrm{P}>0.05)$ between ewes subjected to overfeeding with soybean meal or corn gluten meal (Table 2).

The amount of corn gluten meal utilized (10.9\% DM) did not reduce the DM intake, which suggests that the inclusion of this feedstuff in the diet, at the levels studied, did not bring damage to the rumen microbial population, by occasional RDP shortage. Deficiency in RDP would reduce the DM intake (AFRC, 1993).

The DM intake of ewes subjected to overfeeding with soybean meal or corn gluten meal exceeded the intake of those which received maintenance diet in $58 \%$ and $64 \%$, respectively, and the $\mathrm{CP}$ intake exceeded in $87 \%$ and $100 \%$, respectively. The estimate of ME intake by ewes which were overfed with soybean meal or corn gluten meal (3.1 and $3.2 \mathrm{Mcal} /$ day, respectively) was $61.4 \%$ and $66.6 \%$, respectively, over the estimate of ME intake by ewes receiving maintenance diet (1.92 Mcal/day). According to the NRC (1985), the requirement for maintenance of $50 \mathrm{~kg}$ body weight ewes is $2.0 \mathrm{Mcal} /$ day ME and $95 \mathrm{~g} \mathrm{CP} /$ day. For the same animal under overfeeding, however, the ME intake recommended is $3.4 \mathrm{Mcal} /$ day, and the $\mathrm{CP}$ intake is $150 \mathrm{~g} / \mathrm{day}$.

Ewes subjected to overfeeding had higher weight gain and average daily weight gain $(\mathrm{P}<0.01)$ in relation to those receiving the maintenance diet, which presented little weight loss (Table 3). Weight gain and average daily weight gain did not differ $(\mathrm{P}>0.05)$ between ewes under overfeeding, which can be explained by the similarity in the intake of DM, nutrients and ME. The final BCS was not affected $(\mathrm{P}>0.05)$ by diets. Saunders et al. (2010) did not observe significant difference in the weight gain $(3.14 \mathrm{vs} 2.94 \mathrm{~kg})$ and in the final BCS ( 2.78 vs 2.85 units) of Santa Ines ewes overfed for 28 days with soybean meal or corn gluten meal and cottonseed meal.

No effect of diets was observed $(\mathrm{P}>0.05)$ on REA. However, BFT was higher $(\mathrm{P}=0.04)$ in ewes overfed with soybean meal than with corn gluten meal (Table 4).

Rib-eye area is a characteristic related to the amount of muscle, carcass yield and, especially, prime cuts, whereas BFT is directly linked precocity of growth, sexuality and fatness. The results of this study suggest that animals had already reached their total muscle development, which explains the similarity in the measures concerning REA, and started to utilize ME for deposition of subcutaneous backfat. Such observations corroborate those from Siqueira (1990), who reported higher precocity and speed of growth in the Santa Ines breed in relation to other woolless breeds.

The higher RDP level in the soybean meal, in comparison with that of corn gluten meal, might have favored microbial

Table 2 - Dry matter and nutrient intake of ewes overfed or receiving maintenance diet

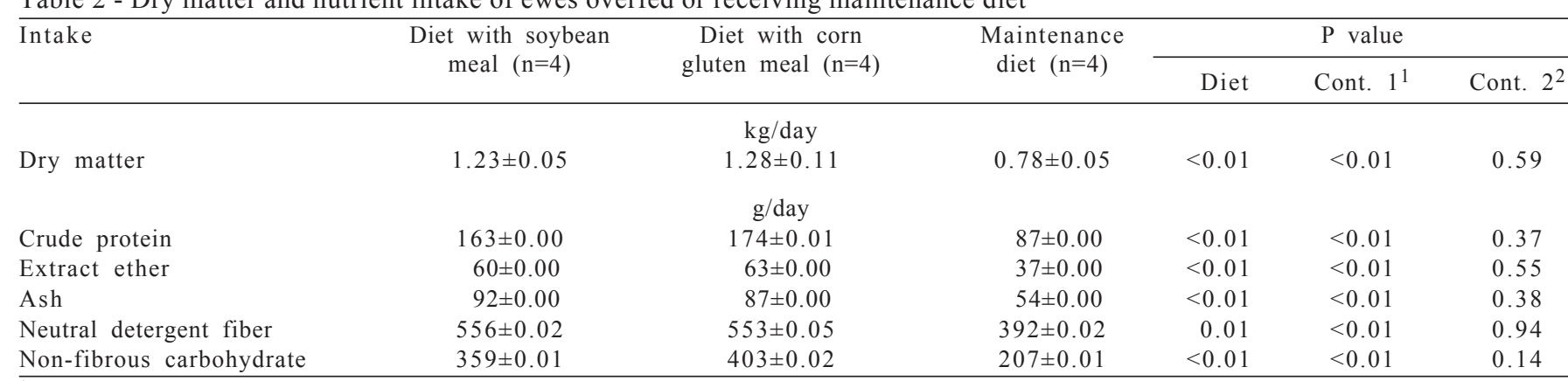

1 Contrast 1 - overfeeding $v s$ maintenance diet.

${ }^{2}$ Contrast 2 - overfeeding with soybean meal vs overfeeding with corn gluten meal. 
activity in the rumen and ruminal digestion of feeds, promoting higher synthesis of volatile fatty acids, which resulted in higher deposition of subcutaneous fat. Fahey Jr. \& Berger (1998) emphasized the importance of the acetate generated at the rumen fermentation as precursor of fatty acids deposited in the adipose tissue. According to these authors, approximately $80 \%$ of the acetate that reaches the liver escapes oxidation, passes into the bloodstream and is used for the synthesis of fatty acids in the tissues.

The PUN concentration in the period before ovulation was higher $(\mathrm{P}<0.01)$ in overfed animals and those overfed with soybean meal (Table 5), which is coherent with the higher CP and RDP intake, respectively. No effect of collection days $(\mathrm{P}>0.05)$ or the diet $\times$ day interaction $(\mathrm{P}>0.05)$ was observed. Berardinelli et al. (2001) also observed higher concentration of PUN in ewes receiving diet with twice the protein requirement recommended for maintenance $(22.2 \mathrm{mg} / \mathrm{dL})$, compared with those receiving diet which met the requirement of protein for maintenance $(12.9 \mathrm{mg} / \mathrm{dL})$. Higher concentration of PUN was also observed by Milis et al. (2005)in ewes fed diets containing soybean meal and wheat bran $(24.9 \mathrm{mg} / \mathrm{dL})$ versus corn gluten meal $(22.5 \mathrm{mg} / \mathrm{dL})$.

Analyzing the PUN concentration after ovulation, effects of diet $(\mathrm{P}<0.05)$ and diet $\times$ day interaction $(\mathrm{P}<0.05)$ were observed. The PUN concentration was higher in overfed ewes in relation to those receiving the maintenance diet on days 6,9 and 12 of the estrous cycles, and it was higher in those subjected to overfeeding with soybean meal in relation to those overfed with corn gluten meal on days 9,12 and 15 of the estrous cycle (Table 6).

Table 3 - Weight gain, average daily weight gain and final body condition score of ewes overfed or receiving maintenance diet

\begin{tabular}{|c|c|c|c|c|c|c|}
\hline \multirow[t]{2}{*}{ Item } & \multirow{2}{*}{$\begin{array}{l}\text { Diet with soybean } \\
\text { meal }(n=4)\end{array}$} & \multirow{2}{*}{$\begin{array}{l}\text { Diet with corn } \\
\text { gluten meal }(n=4)\end{array}$} & \multirow{2}{*}{$\begin{array}{l}\text { Maintenance } \\
\text { diet }(n=4)\end{array}$} & \multicolumn{3}{|c|}{$\mathrm{P}$ value } \\
\hline & & & & Diet & Cont. $1^{1}$ & Cont. $2^{2}$ \\
\hline Weight gain $(\mathrm{kg})$ & $4.82 \pm 1.20$ & $5.35 \pm 1.96$ & $-0.10 \pm 1.18$ & 0.04 & 0.01 & 0.78 \\
\hline Average daily weigh gain $(\mathrm{kg})$ & $0.11 \pm 0.02$ & $0.13 \pm 0.04$ & $-0.01 \pm 0.02$ & 0.04 & 0.01 & 0.78 \\
\hline Body condition score ${ }^{3}$ & $2.81 \pm 0.06$ & $3.18 \pm 0.32$ & $2.93 \pm 0.18$ & 0.40 & - & - \\
\hline
\end{tabular}

${ }^{1}$ Contrast 1 - overfeeding vs maintenance diet.

2 Contrast 2 - overfeeding with soybean meal vs overfeeding with corn gluten meal.

${ }^{3}$ Scale: 0 - emaciated; 5 -overfat.

Table 4 - Rib-eye area and back fat thickness of ewes overfed or receiving maintenance diet

\begin{tabular}{|c|c|c|c|c|c|c|}
\hline \multirow[t]{2}{*}{ Item } & \multirow{2}{*}{$\begin{array}{l}\text { Diet with soybean } \\
\text { meal }(n=4)\end{array}$} & \multirow{2}{*}{$\begin{array}{l}\text { Diet with corn } \\
\text { gluten meal }(n=4)\end{array}$} & \multirow{2}{*}{$\begin{array}{l}\text { Maintenance } \\
\text { diet }(n=4)\end{array}$} & \multicolumn{3}{|c|}{$\mathrm{P}$ value } \\
\hline & & & & Diet & Cont. $1^{1}$ & $\overline{\text { Cont. } 2^{2}}$ \\
\hline Rib-eye area $\left(\mathrm{cm}^{2}\right)$ & $10.11 \pm 0.46$ & $9.44 \pm 1.15$ & $9.69 \pm 1.13$ & 0.87 & - & - \\
\hline Back-fat thickness $(\mathrm{cm})$ & $0.40 \pm 0.04$ & $0.31 \pm 0.01$ & $0.33 \pm 0.02$ & 0.08 & 0.33 & 0.04 \\
\hline
\end{tabular}

${ }_{1}$ Contrast 1 - overfeeding vs maintenance diet.

2 Contrast 2 - overfeeding with soybean meal vs overfeeding with corn gluten meal.

Table 5 - Plasma urea nitrogen concentration before and after ovulation of ewes overfed or receiving maintenance diet

\begin{tabular}{|c|c|c|c|c|c|c|c|c|}
\hline \multirow[t]{2}{*}{ Item } & \multirow{2}{*}{$\begin{array}{l}\text { Diet with soybean } \\
\text { meal }(n=4)\end{array}$} & \multirow{2}{*}{$\begin{array}{l}\text { Diet with corn } \\
\text { gluten meal }(n=4)\end{array}$} & \multirow{2}{*}{$\begin{array}{l}\text { Maintenance } \\
\text { diet }(n=4)\end{array}$} & \multicolumn{5}{|c|}{$\mathrm{P}$ value } \\
\hline & & & & Diet & Time & $\mathrm{D}^{*} \mathrm{~T}^{1}$ & Cont. $1^{2}$ & Cont. $2^{3}$ \\
\hline PUN-1 & $239+092$ & $\begin{array}{c}\mathrm{mg} / \mathrm{dL} \\
198+0.88\end{array}$ & $176+083$ & $<001$ & 0.73 & 025 & $<001$ & $<001$ \\
\hline PUN-2 & $26.0 \pm 1.01$ & $21.6 \pm 0.90$ & $21.0 \pm 0.80$ & 0.02 & 0.84 & 0.03 & 0.06 & 0.02 \\
\hline
\end{tabular}

PUN-1 = plasma urea nitrogen before ovulation; PUN-2 = plasma urea nitrogen after ovulation.

${ }^{1} \mathrm{D} * \mathrm{~T}=$ diet $\times$ time (days of collection) interaction.

2 Contrast 1 - overfeeding vs maintenance diet.

${ }^{3}$ Contrast 2 - overfeeding with soybean meal vs overfeeding with corn gluten meal.

Table 6 - Plasma urea nitrogen concentration on days 3, 6, 9, 12 and 15 after ovulation in ewes overfed or receiving maintenance diet

\begin{tabular}{|c|c|c|c|c|c|c|}
\hline \multirow[t]{2}{*}{ Collection days } & \multirow{2}{*}{$\begin{array}{c}\text { Diet with soybean } \\
\text { meal }(n=4)\end{array}$} & \multirow{2}{*}{$\begin{array}{l}\text { Diet with corn } \\
\text { gluten meal }(n=4)\end{array}$} & \multirow{2}{*}{$\begin{array}{c}\text { Maintenance } \\
\text { diet }(n=4)\end{array}$} & \multicolumn{3}{|c|}{$\mathrm{P}$ value } \\
\hline & & & & Diet & Cont. $1^{1}$ & Cont. $2^{2}$ \\
\hline 3 & $24.61 \pm 2.00$ & $22.00 \pm 0.47$ & $21.42 \pm 1.85$ & 0.44 & - & - \\
\hline 6 & $23.59 \pm 2.83$ & $24.31 \pm 1.70$ & $18.55 \pm 0.53$ & 0.06 & 0.02 & 0.77 \\
\hline 9 & $27.62 \pm 1.47$ & $20.85 \pm 2.82$ & $19.71 \pm 0.76$ & $<0.01$ & 0.04 & 0.01 \\
\hline 12 & $28.16 \pm 1.75$ & $21.48 \pm 0.80$ & $20.26 \pm 2.31$ & $<0.01$ & 0.04 & 0.01 \\
\hline 15 & $26.26 \pm 3.18$ & $19.28 \pm 2.56$ & $25.26 \pm 1.26$ & 0.02 & 0.26 & $<0.01$ \\
\hline
\end{tabular}

${ }^{1}$ Contrast 1 - overfeeding vs maintenance diet.

${ }^{2}$ Contrast 2 - overfeeding with soybean meal vs overfeeding with corn gluten meal. 
The plasma progesterone concentration did not differ $(\mathrm{P}>0.05)$ between ewes overfed or receiving the maintenance diet, and it was higher $(\mathrm{P}<0.05)$ in those overfed with soybean meal in comparison with corn gluten meal (Table 7). The difference between overfed ewes was observed on days 3, 6, 9, 12 and 15 of the estrous cycle (Figure 1). No diet $\times$ day interaction was observed $(\mathrm{P}>0.05)$. Higher plasma progesterone concentration was also observed in ewes with high PUN concentration by Berardinelli et al. (2001).

Increase in DM intake promotes increase in the progesterone metabolization rate by means of higher flow of blood towards the liver, which is the main local for clearance of this hormone (Freetly \& Ferrell, 1994), resulting in lower blood progesterone concentration. Opposite to the observations of this experiment, Rhind et al. (1989), Lozano et al. (1998) and O'Callanghan et al. (2000) observed difference in the blood progesterone concentration in ewes subjected to different feeding programs. However, in these studies, ewes presenting lower blood progesterone concentration ingested twice to four times more ME than those with higher concentration of this hormone. Thus, it is possible that the difference in DM and ME intake in ewes overfed and receiving maintenance diet in this study was not enough to bring about alterations in the plasma progesterone concentration. Other factors, such as breed and body weight, can also be involved, affecting the blood flow to the hepatic portal vein (Huntington et al., 1981).

The mechanism related to higher plasma progesterone concentration in ewes under overfeeding with soybean meal can be related to the better biological value of the protein from soybean meal in relation to that of corn gluten meal, especially when considering the profile of essential amino acids such as lysine and methionine. Lipoproteins, especially LDL and HDL, which are rich in methionine and lysine (Auboiron et al., 1995), are essential for the transport of cholesterol, which is the precursor of biosynthesis of steroid hormones such as estrogens and progesterone (Hall, 1994).

The follicular growth of ewes which received maintenance diet occurred in two $(n=2)$, three $(n=1)$ or four $(\mathrm{n}=1)$ waves. All ewes which received overfeeding presented three follicular waves. As observed in this study, the predominance of three follicular waves was also observed by Evans et al. (2000), in cyclic Texel ewe lambs and crossbred Suffolk $\times$ Texel (64.5\%) and by Ali et al. (2006), in cyclic Ossimi ewe lambs (65\%).

There was no effect of diets on the interval of ovulations ( $\mathrm{P}>0.05$, Table 8$)$. The results were similar to those of Ravindra et al. (1994), who observed 17.2 days between ovulations in Western White Face ewes and those of Ginther et al. (1995), who verified, on average, 17.7 days between ovulations in Polypay ewe lambs.

The number of ovulations in overfed ewes was higher than that observed in those receiving the maintenance diet $(\mathrm{P}<0.05$; Table 8$)$. Increase in the number of ovulations in response to overfeeding with protein feeds was also observed by Nottle et al. (1988), Downing et al. (1995) and Molle et al. $(1995,1997)$. Supplementation with protein feeds results in significant increase in the amount of postrumen digested protein (Nottle et al., 1988) and increase in the plasma gluconeogenic amino acids and insulin concentration (Downing et al., 1995). In addition, the higher intake of energy by ewes under overfeeding possibly caused increase in the blood glucose, insulin and IGF-I concentration. Insulin directly stimulates both mitosis and production of steroids in granulosa (Gutierrez et al., 1997)

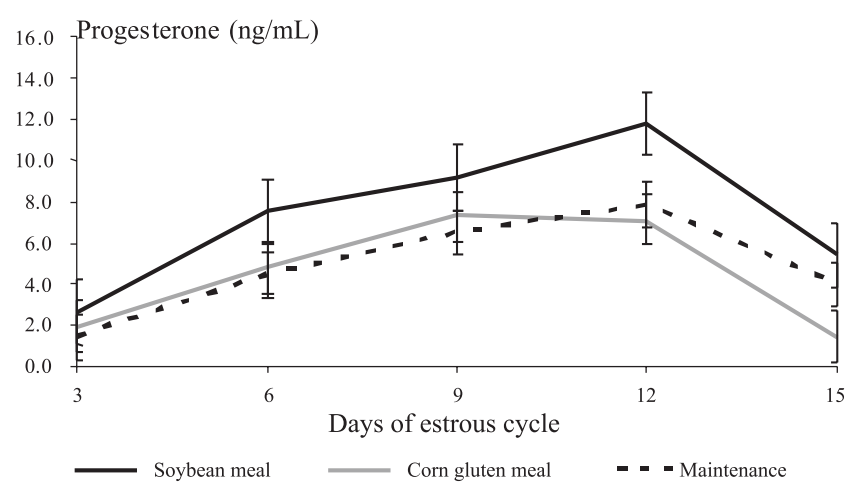

Figure 1 - Plasma progesterone concentration in the first 15 days of the estrous cycle in ewes overfed or receiving maintenance diet.

Table 7 - Plasma progesterone concentration in ewes overfed or receiving maintenance diet

\begin{tabular}{|c|c|c|c|c|c|c|c|c|}
\hline \multirow[t]{2}{*}{ Item } & \multirow{2}{*}{$\begin{array}{l}\text { Diet with soybean } \\
\text { meal }(\mathrm{n}=4)\end{array}$} & \multirow{2}{*}{$\begin{array}{l}\text { Diet with corn } \\
\text { gluten meal }(n=4)\end{array}$} & \multirow{2}{*}{$\begin{array}{l}\text { Maintenance } \\
\text { diet }(\mathrm{n}=4)\end{array}$} & \multicolumn{5}{|c|}{$\mathrm{P}$ value } \\
\hline & & & & Diet & Day & $\mathrm{D}^{*} \mathrm{~T}^{1}$ & Cont. $1^{2}$ & Cont. $2^{3}$ \\
\hline Progesterone & $7.28 \pm 0.96$ & $\begin{array}{c}\mathrm{ng} / \mathrm{mL} \\
4.63 \pm 0.65\end{array}$ & $4.82 \pm 0.73$ & $<0.07$ & $<0.01$ & 0.65 & 0.28 & 0.03 \\
\hline
\end{tabular}


and theca (Stewart et al., 1995) cells, and IGF-I increases the sensitivity of cells to FSH (Adashi et al., 1985), promoting follicular development (Webb et al., 2004). Overfeeding can also increase the number of ovulations for resulting in higher hepatic metabolization of steroid hormones, consequently, decreasing the negative feedback of such hormones on the release of gonadotropins FSH and LH (Smith \& Stewart, 1990).

The number of ovulations did not differ $(\mathrm{P}>0.05)$ between ewes overfed with soybean meal or corn gluten meal (Table 8). Similar results were observed by Branca et al. (2000) in Sarda ewes subjected to overfeeding with soybean meal or corn gluten meal for 14 days and by Saunders et al. (2010), in ewes overfed with soybean meal or corn gluten meal and cottonseed meal for 28 days.

The average ovulatory follicle diameter did not differ $(\mathrm{P}>0.05)$ between ewes overfed or receiving the maintenance diet (Table 8) and was similar to the results found by Ravindra et al. (1994), of $6.9 \mathrm{~mm}$; Ginther et al. (1995), of $5.9 \mathrm{~mm}$ and Evans et al. (2000), of $6.4 \mathrm{~mm}$. Saunders et al. (2010) also did not observe difference in the ovulatory follicle diameter between ewes overfed with soybean meal $(6.6 \mathrm{~mm})$ or corn gluten meal and cottonseed meal $(6.7 \mathrm{~mm})$ for 28 days.

The day of emergence of waves, the end of waves, the waves length, the interval of waves and the number of follicles per waves did not differ $(\mathrm{P}>0.05)$ between ewes overfed or receiving the maintenance diet (Table 9).

Ali et al. (2006) verified that the emergence of waves occurred on days $-0.3 ; 5.3$ and 11.7 of the estrous cycle, similarly to those in this study. Evans et al. (2000) observed that the end of the first and second waves occurred afterwards, whereas for the third wave it occurred before the observed in this study (days 11.0; 14.4 and 15.3 of the estrous cycle, respectively). The length of waves one and two was 8.9 and 7.5 days, respectively. These values are close to the observed in this study. However, the length of the third wave was of only 4.4 days.

The interval of waves observed in this study corroborates the observations of Rubianes (2000), who reported that in small ruminants, waves emerge with intervals of four to six days, with interaction between ovarian steroids and gonadotropins responsible for the regulation of these intervals.

The number of ovarian follicles in each follicular wave was similar to that verified by Grazul-Bilska et al. (2006), who also did not observe difference between ewes fed ad libitum or under feed restriction ( $60 \%$ of the requirement for maintenance) and treated with FSH. However, Ginther et al. (1995) reported smaller number of follicles per wave $(1.6 ; 1.1 ; 1.3 ; 1.5$ follicles in waves one, two, three and four, respectively).

Table 8 - Interval of ovulations, number of ovulations and average ovulatory follicle diameter of ewes overfed or receiving maintenance diet

\begin{tabular}{|c|c|c|c|c|c|c|}
\hline \multirow[t]{2}{*}{ Item } & \multirow{2}{*}{$\begin{array}{c}\text { Diet with soybean } \\
\text { meal }(n=4)\end{array}$} & \multirow{2}{*}{$\begin{array}{l}\text { Diet with corn } \\
\text { gluten meal }(n=4)\end{array}$} & \multirow{2}{*}{$\begin{array}{l}\text { Maintenance } \\
\text { diet }(n=4)\end{array}$} & \multicolumn{3}{|c|}{$\mathrm{P}$ value } \\
\hline & & & & Diets & Cont. $1^{1}$ & Cont. $2^{2}$ \\
\hline Interval of ovulations (days) & $17.25 \pm 0.62$ & $16.50 \pm 0.28$ & $17.25 \pm 0.62$ & 0.57 & - & - \\
\hline Number of ovulations & $2.50 \pm 0.28$ & $2.00 \pm 0.00$ & $1.50 \pm 0.28$ & 0.06 & 0.04 & 0.18 \\
\hline Average ovulatory follicle diameter ( $\mathrm{mm})$ & $6.36 \pm 0.56$ & $6.20 \pm 0.05$ & $6.87 \pm 0.33$ & 0.36 & - & - \\
\hline
\end{tabular}

1 Contrast 1 - overfeeding vs maintenance diet.

${ }^{2}$ Contrast 2 - overfeeding with soybean meal vs overfeeding with corn gluten meal.

Table 9 - Characteristics of follicular waves of ewes overfed or receiving maintenance diet that presented three follicular waves

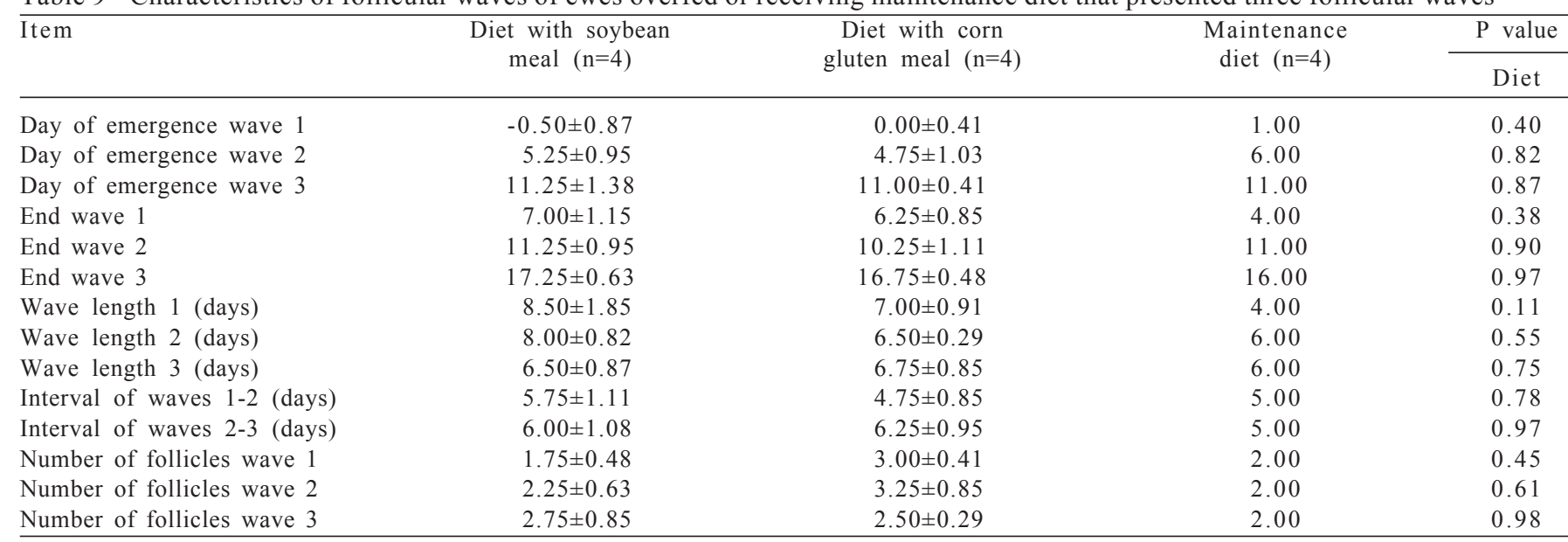


The maximum diameter of the largest follicle of the first $(\mathrm{P}<0.05)$ and second $(\mathrm{P}<0.01)$ waves was higher in overfed ewes in relation to those receiving maintenance diet (Table 10), which may be related to the great energy and protein intake of these animals. The maximum diameter of the largest follicle of the second wave was higher $(\mathrm{P}<0.01)$ in ewes overfed with soybean meal than with corn gluten meal. Soybean meal, for being a feedstuff with excellent amino acid profile, can stimulate the synthesis of insulin. Elevated plasma insulin concentration was observed in sheep receiving amino acids of branched chain by infusion (Kuhara et al., 1991) or fed excessive protein originated from soybean meal (Molle et al., 1995) or lupine grains (Downing et al., 1995).

Ravindra et al. (1994) observed that the maximum diameter of the largest follicle was $5.5 \mathrm{~mm}$ in the first, $4.3 \mathrm{~mm}$ in the second and $6.9 \mathrm{~mm}$ in the third waves and Ali et al. (2006) verified that the largest follicle of the first, second and third waves reached maximum diameter of $6.0 \mathrm{~mm}$. The smaller diameter achieved by the largest follicle of the second wave in comparison with the ovulatory wave in this study may be attributed to the negative influence of the plasma progesterone concentration during its development, as suggested by Rubianes et al. (1996). The inhibition of the LH pulse frequency by progesterone during the luteal phase of the cycle results in less follicular development (Savio et al., 1993).

The day on which the largest follicle of each wave reached maximum diameter did not differ between ewes receiving the different diets (Table 10). Values close to the observed were reported by Ali et al. (2006): days 3.89 in the first, 10.85 in the second, and 16.3 in the third waves.

The growth phase of the largest follicle of each wave did not differ $(\mathrm{P}>0.05)$ between ewes receiving different diets. The growth rate of the largest follicle of the first wave was higher in ewes subjected to overfeeding $(\mathrm{P}<0.08)$ and in those overfed with corn gluten meal $(\mathrm{P}<0.01)$. However, the growth rate of the largest follicle of the third wave was higher in ewes which received the maintenance $\operatorname{diet}(\mathrm{P}<0.01)$ and in those overfed with soybean meal $(\mathrm{P}<0.05$; Table 10$)$. Based on such results, it was not possible to establish a relation between energy and protein intake or between protein degradability and follicular growth rate.

The growth rate observed in this study is lower than that reported by Ravindra et al. (1994), which was $1.0 \mathrm{~mm}$ /day in the first wave, $1.1 \mathrm{~mm} /$ day in the second wave and $1.2 \mathrm{~mm} /$ day in the ovulatory wave. Ginther et al. (1995) also observed higher growth rate in waves one, two, three and in the ovulatory one $(0.8 ; 1.0 ; 1.0 ; 0.9 \mathrm{~mm} /$ day, respectively) than observed in this study.

Table 10 - Characteristics of follicular waves of ewes overfed or receiving maintenance diet that presented three follicular waves

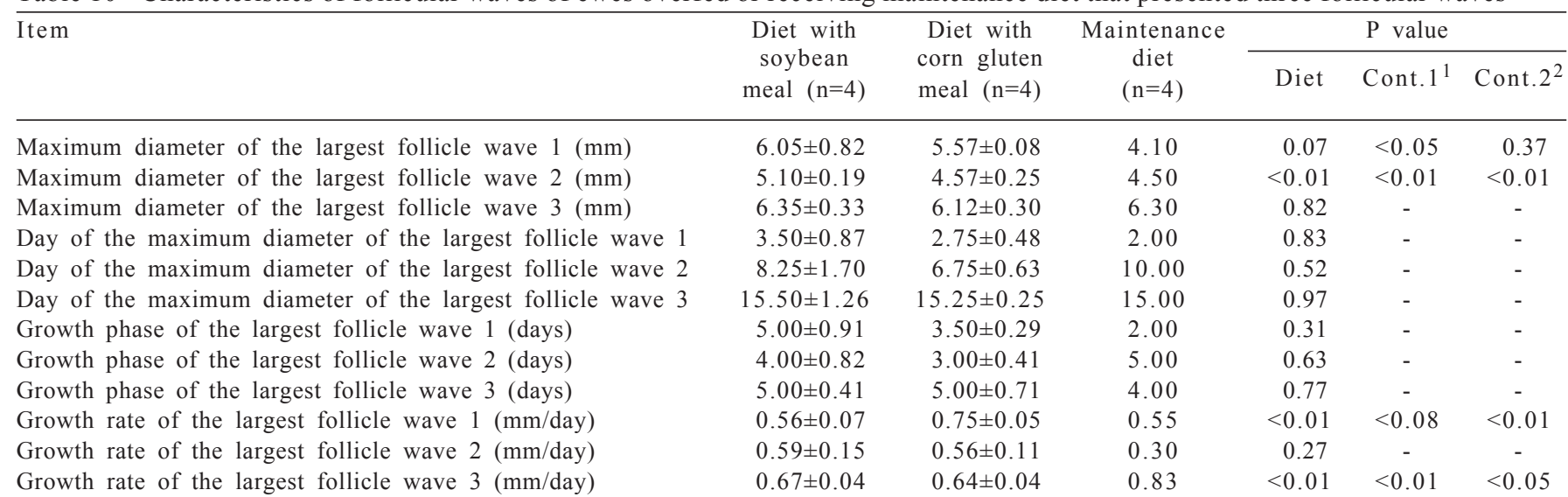

1 Contrast 1 - overfeeding $v$ s maintenance diet.

2 Contrast 2 - overfeeding with soybean meal vs overfeeding with corn gluten meal.

\section{Conclusions}

Overfeeding with soybean meal and corn gluten meal can be a strategy to increase the number of ovulations in Santa Ines ewes. Overfeeding with soybean meal can be an efficient practice to increase the plasma progesterone concentration in Santa Ines ewes. Higher energy and protein intake in ewes subjected to overfeeding positively affects the diameter of the largest follicle of anovulatory waves.

\section{References}

ADASHI, E.Y.; RESNICK, C.E.; D'ERCOLE, A.J. et al. Insulin-like growth factors as intraovarian regulators of granulosa cells growth and function. Endocrinology Reviews, v.6, n.3, p.400-420, 1985. 
AGRICULTURAL AND FOOD RESEARCH COUNCIL. Energy and protein requirements of ruminants. Wallingford: $C A B$ International, 1993. 159p.

ALI, A.; DERAR, R.; HUSSEIN, H. Seasonal variation of the ovarian follicular dynamics and luteal functions of sheep in the subtropics. Theriogenology, v.66, n.2, p.463-469, 2006.

ALVES, N.G.; TORRES, C.A.; GUIMARÃES, J.D. et al. Effect of urea in the diet on ovarian follicular dynamics and plasma progesterone concentration in Alpine goats. Revista Brasileira de Zootecnia, v.40, p.1512-1518, 2011.

ARMSTRONG, D.C.; MC EVOY, T.G.; BAXTER, G. Effect of dietary energy and protein on bovine follicular dynamics and embryo production in vitro: association with the ovarian insulinlike growth factor system. Biology of Reproduction, v.64, n.6, p.1624-1632, 2001.

ASSOCIATION OF OFFICIAL ANALYTICAL CHEMISTS - AOAC. Official methods of analytical of the Association of Official Analytical Chemists. 15.ed. Washington, 1990. v.2, $1422 \mathrm{p}$.

AUBOIRON, S.; DURAN, D.; ROBERT, J.C. et al. Effects of dietary fat and L-methinonine on the hepatic metabolism of very low density lipoproteins in the preruminant calf, Bos spp. Reproduction Nutrition Development, v.35, n.2, p.167-178, 1995.

BERARDINELLI, J.G.; WENIG, J.; BURFENING, P.J. et al. Effect of excess degradable intake protein on early embryonic development, ovarian steroid and blood urea nitrogen on days $2,3,4$, and 5 of the estrus cycle in mature ewes. Journal of Animal Science, v.79, n.1, p.193-199, 2001

BRANCA, A.; MOLLE, G.; SITZIA, M. et al. Short-term dietary effects on reproductive wastage after induced ovulation and artificial insemination in primiparous lactating Sarda ewes. Animal Reproduction Science, v.58, n.1/2, p.59-71, 2000.

DOWNING, J.A.; JOSS, J.; SCARAMUZZI, R.J. A mixture of the branched chain amino acids leucine, isoleucine and valine increases ovulation rate in ewes when infused during the luteal phase of the oestrous cycle: an effect that may be mediated by insulin. Journal of Endocrinology, v.145, n.2, p.315-323, 1995.

EVANS, A.C.O.; DUFFY, P.; HYNES, N. et al. Waves of follicle development during the estrous cycle in sheep. Theriogenology, v.53, n.3, p.699-715, 2000.

FAHEY JR., G.C.; BERGER, L.L. Carbohydrate nutrition of ruminants. In: CHURCH, D.C. (Ed.). The ruminant animal: digestive physiology and nutrition. New Jersey: Prentice Hall, 1998. p.269-297.

FREETLY, H.C.; FERRELL, C.L. Net uptakes of oestradiol-17ß and progesterone across the portal-drained viscera and the liver of ewes. Journal of Endocrinology, v.141, n.2, p.353-358, 1994.

GARCIA-BOJALIL, C.M.; STAPLES, C.R.; RISCO, C.A. et al. Protein degradability and calcium salts of long-chain fatty acids in the diets of lactating dairy cows: reproductive responses. Journal of Dairy Science, v.81, n.5, p.1385-1395, 1998.

GINTHER, O.J.; KOT, K.; WILTBANK, M.C. Associations between emergence of follicular waves and fluctuations in FSH concentrations during the estrous cycle in ewes. Theriogenology, v.43, n.3, p.689-703, 1995.

GORDON, I. Controlled reproduction in sheep \& goats. New York: CAB International, 1997. v.2, 450p.

GRAZUL-BILSKA, A.T.; BOROWCZYK, E.; ARNDT, W. et al. Effects of overnutrition and undernutrition on in vitro fertilization (IVF) and early embryonic development in sheep. Sheep and Beef Day, v.47, p.56-66, 2006.

GUTIERREZ, C.G.; CAMPBELL, B.K.; WEBB, R. Development of a long-term bovine granulosa cell culture system: induction and maintenance of estradiol production, response to folliclestimulating hormone, and morphological characteristics. Biology of Reproduction, v.56, n.3, p.608-616, 1997.

HALL, P. F. Testicular steroid synthesis: organization and regulation. In: KNOBIL, E.; NEILL, J.D. (Eds.). The physiology of reproduction. 2.ed. New York: Raven, 1994. v.2, p.363-410.
HUNTINGTON, G.B.; PRIOR, R.L.; BRITTON, R.A. Glucose and lactate absorption and metabolic interrelationships in steers changed from low to high concentrate diets. Journal of Nutrition, v.111, n.7, p.1164-1172, 1981

JORDAN, E.R.; CHAPMAN, T.E.; HOLTAN, D.W. et al Relationship of dietary crude protein to composition of uterine secretions and blood in high-producing postpartum dairy cows. Journal of Dairy Science, v.66, n.8, p.1854-1862, 1983.

KUHARA, T.; IKEDA, S.; OHNEDA, A. et al. Effects of intravenous infusion of 17 amino acids on the secretion of GH, glucagon, and insulin in sheep. American Journal of Physiology, v.260, n. 1, p.21-26, 1991 .

LAVEN, R.A.; DAWUDA, P.M.; SCARAMUZZI, R.J. et al. The effect of feeding diets high in quickly degradable nitrogen on follicular development and embryo growth in lactating Holstein dairy cows. Animal Reproduction Science, v.84, n.1/2, p.41-52, 2004.

LOZANO, J.M.; ABECIA, A.; FORCADA, F. et al. Effect of undernutrition on the distribution of progesterone in the uterus of ewes during the luteal phase of the estrous cycle. Theriogenology, v.49, n.3, p.539-546, 1998.

McCULlAGH, P.; NELDER, J.A. Generalized linear model 2.ed. London: Chapman and Hall, 1989. 511p.

Mc EVOY, T.G.; ROBINSON, J.J.; AITKEN, R.P. et al. Dietaryinduced suppression of preovulatory progesterone concentrations in superovulated ewes impairs the subsequent in vivo and in vitro development of their ova. Animal Reproduction Science, v.39, n.2, p.89-107, 1995.

MILIS, C.; LIAMADIS, D.; ROUBIES, N. et al. Comparison of corn gluten products and soybean-bran mixture as sources of protein for lactating Chios ewes. Small Ruminant Research, v. 58, n. 3, p. $237-244,2005$.

MOLLE, G.; BRANCA, A.; LIGIOS, S. et al. Effect of grazing background and flushing supplementation on reproductive performance in Sarda ewes. Small Ruminant Research, v.17, n.3, p.245-254, 1995.

MOLLE, G.; LANDAU, S.; BRANCA, A. et al. Flushing with soybean meal can improve reproductive performances in lactating Sarda ewes on a mature pasture. Small Ruminant Research, v.24, n.3, p.157-165, 1997.

NATIONAL RESEARCH COUNCIL. Nutrients requirements of sheeps. 6.ed. Washington: National Academy, 1985. 99p.

NOTTLE, M.B.; HYND, P.I.; SEAMARK, R.F. et al. Increases in ovulation rate in lupin-fed ewes are initiated by increases in protein digested post-ruminally. Journal of Reproduction and Fertility, v.84, n.2, p.563-566, 1988

O'CALlaGHAN, D.; YAAKUB, H.; HYTTEL, P. Effect of nutrition and superovulation on oocyte morphology, follicular fluid composition hormone concentration in ewes. Journal of Reproduction and Fertility, v.118, n.2, p.303-313, 2000.

PARR, R.A.; DAVIS, I.F.; MILES, M.A. et al. Feed intake affects metabolic cleareance rate of progesterone in sheep. Research in Veterinary Science, v.55, n.3, p.306-310, 1993.

RAVINDRA, J.P.; RAWLINGS, N.C.; EVANS, A.C.O. et al. Ultrasonic study of ovarian follicular dynamics in ewes during the estrous cycle. Journal of Reproduction and Fertility, v. 101, n.2, p.501-509, 1994.

RHIND, S.M.; McKELVEY, W.A.C.; McMILLEN, S.R. et al. Effect of restricted food intake before and/or after mating, on the reproductive performance of Greyface ewes. Animal Production, v.48, n.2, p.149-155, 1989.

RUBIANES, E. Control farmacológico del ciclo estral em caprinos y ovinos. In: SIMPÓSIO CONTROLE FARMACOLÓGICO DO CICLO ESTRAL EM RUMINANTES, 1., 2000, São Paulo. Anais... São Paulo: Fundação da Faculdade de Medicina Veterinária e Zootecnia da Universidade de São Paulo, 2000. p.255-282.

RUBiAneS, E.; CASTRO, T.; CARBAJAL, B. Effect of high progesterone levels during the growing phase of the dominant 
follicle of wave 1 in ultrasonically monitored ewes. Canadian Journal Animal Science, v.76, p.473-475, 1996.

SAUNDERS, G.A.; ALVES, N.G.; PEREZ, J.R.O. et al. Efeito da sobrealimentação com fontes de proteína de diferentes degradabilidades sobre a ovulação em ovelhas Santa Inês. Revista Brasileira de Zootecnia, v.39, p.2731-2738, 2010.

SAVIO, J.D.; THATCHER, W.W.; BADINGA, L. et al. Regulation of dominant follicle turnover during the oestrous cycle in cows. Journal of Reproduction and Fertility, v.97, p.197-203, 1993.

SIQUEIRA, E.R. Estratégias de alimentação do rebanho e tópicos sobre produção de carne ovina. In: PRODUÇÃO DE OVINOS, 1990, Jaboticabal. Anais... Jaboticabal: FUNEP, 1990. p.157-171.

SMALL RUMINANT NUTRITION SYSTEM - SRNS. Versão 1.8.4. College Station: Texas University, 2008. 8p.

SMITH, A.J.; STEWART, R.D. Effects of nutrition on the ovulation rate of ewes. In: OLDHAM, C.M.; MARTIN, G.B.; PURVIS I.W. (Eds.). Reproductive physiology of merino sheep concepts and consequences. Perth: University of Western Australia, 1990. p. 85-101.

SONDERMAN, J.P.; LARSON, L.L. Effect of dietary protein and exogenous gonadotropin-releasing hormone on circulating progesterone concentrations and performance of Holstein cows Journal of Dairy Science, v.72, n.8, p.2179-2183, 1989.

STEWART, R.E.; SPICER, L.J.; HAMILTON, T.D. et al. Effects of insulin like growth factor I and insulin on proliferation and on basal and luteinizing hormoneinduced steroidogenesis of bovine thecal cells: involvement of glucose and receptors for insulin-like growth factor I and luteinizing hormone. Journal of Animal Science, v.73, n.12, p.3719-3731, 1995.

VIÑOLES, C.; MEIKLE, A.; MARTIN, G.B. Short-term nutritional treatments grazing legumes or feeding concentrates increase prolificacy in Corriedale Ewes. Animal Reproduction Science, v.113, n.1, p.82-92, 2008

WEBB, R.; GARNSWORTHY, P.C.; GONG, J.G. et al. Control of follicular growth: local interactions and nutritional influences. Journal of Animal Science, v.82, n.13, p.63-74, 2004. 